\title{
The Impact of Climate Change on Agriculture Production in Ethiopia: Application of a Dynamic Computable General Equilibrium Model
}

\author{
Rahel Solomon1, Belay Simane ${ }^{2 *}$, Benjamin F. Zaitchik ${ }^{3}$ \\ ${ }^{1}$ Ethiopian Development Research Institute (EDRI), Addis Ababa, Ethiopia \\ ${ }^{2}$ College of Development Studies, Addis Ababa University, Addis Ababa, Ethiopia \\ ${ }^{3}$ Department of Earth and Planetary Sciences, Johns Hopkins University, Baltimore, MD, USA \\ Email: richedri@yahoo.com, ‘belay.simane@aau.edu.et, zaitchik@jhu.edu
}

How to cite this paper: Solomon, R., Simane, B., \& Zaitchik, B. F. (2021). The Impact of Climate Change on Agriculture Production in Ethiopia: Application of a Dynamic Computable General Equilibrium Model. American Journal of Climate Change, 10, 32-50.

https://doi.org/10.4236/ajcc.2021.101003

Received: October 13, 2020

Accepted: March 14, 2021

Published: March 17, 2021

Copyright $\odot 2021$ by author(s) and Scientific Research Publishing Inc. This work is licensed under the Creative Commons Attribution International License (CC BY 4.0).

http://creativecommons.org/licenses/by/4.0/

\begin{abstract}
The challenge of meeting the ever-increasing food demand for the growing population will be further exacerbated by climate change in Ethiopia. This paper presents the simulated economy-wide impacts of climate change on the agriculture sector of Ethiopia using a dynamic computable general equilibrium (CGE) model. The study simulated the scenarios of agricultural productivity change induced by climate change up to the year 2050. At national level, the simulation results suggest that crop production will be adversely affected during the coming four decades and the severity will increase over the time period. Production of teff, maize and sorghum will decline by 25.4, 21.8 and 25.2 percent, respectively by 2050 compared to the base period. Climate change will also cause losses of 31.1 percent agricultural GDP at factor cost by 2050. Climate change affects more the income and consumption of poor rural households than urban rural non-farming households. The reduction in agricultural production will not be evenly distributed across agro ecological zones, and will not all be negative. Among rural residents, climate change impacts tend to hurt the income of the poor more in drought prone regions. Income from labor, land and livestock in moisture sufficient highland cereal-based will decline by 5.1, 8.8 and 15.2 percent in 2050. This study indicated that since climate change is an inevitable phenomenon, the country should start mainstreaming adaptation measures to sustain the overall performance of the economy.
\end{abstract}

\section{Keywords}

Adaptation, Climate Change, Dynamic Computable General Equilibrium 
Model

\section{Introduction}

Agriculture remains the main activity in the Ethiopian economy and contributes, on average, 44 percent of GDP and employs over 80 percent of the population (MoFED, 2013). Smallholder households produce more than 90 percent of the agricultural output and cultivate more than 90 percent of the total cropped land. Crop production is the dominant subsector, accounting for more than 60 percent of agricultural GDP, followed by livestock with 20 percent. It is estimated that 16.5 million hectares ( 14.8 percent) of the country's land area is potentially suitable for agricultural production. The potentially irrigable land in the country is about 3.7 million hectares. Ethiopia has the largest livestock population in Africa and the tenth-largest in the world, with about 70 million head of livestock.

With a current growth rate of about 2.8 percent per year, Ethiopia's population is expected to reach 129 million by 2030. Almost two million persons are added annually to the population. Given the high proportion of the population living in rural areas, increasing pressure is put on natural resources, increasing demand for productivity and scarce arable land at the expense of greener land uses such as pasture, and forests, bringing further degradation. Meeting the food demand for this growing population is already a formidable challenge for the agriculture sector, but it will be further exacerbated by climate change. Over the next 50 years, Ethiopia is expected to experience increasingly erratic weather, with higher rainfall, and a temperature rise of at least $3^{\circ} \mathrm{C}(\mathrm{McSw}$ eeney et al. 2010). This could result in prolonged droughts and floods, which would affect crop yields as well as increase existing tension around resource use (Simane et al., 2012). Deforestation, accelerated soil erosion, and land degradation are also serious environmental problems that affect the future food security of the country. Therefore, mainstreaming climate change issues into the national development plans and processes is important to reduce the impacts of climate change on poverty reduction and thereby the development of the country (IPCC, 2007).

The Government of Ethiopia has made and continues to make significant efforts to address poverty in rural areas. The Government of the Federal Democratic Republic of Ethiopia has also initiated the Climate-Resilient Green Economy (CRGE) initiative to protect the country from the adverse effects of climate change and to build a green economy that will help realize its ambition of reaching middle income status before 2025 (EPA, 2011). The objective is to identify green economy opportunities that could help Ethiopia reach its ambitious growth targets while keeping greenhouse gas emissions low. The government intends to attract development partners to help implement this new and 
sustainable growth model and to become a "green economy front-runner".

The Climate-Resilient Green Economy (CRGE) initiative follows a sectoral approach and has so far identified and prioritized more than 60 initiatives, which could help the country achieve its development goals while limiting 2030 GHG emissions to around today's $150 \mathrm{Mt} \mathrm{CO}_{2} \mathrm{e}$ around $250 \mathrm{Mt} \mathrm{CO}_{2} \mathrm{e}$ less than estimated under a conventional development path. The green economy plan is based on four pillars (Improving crop and livestock production practices for higher food security and farmer income while reducing emissions, Protecting and re-establishing forests for their economic and ecosystem services, including as carbon stocks; Expanding electricity generation from renewable sources of energy for domestic and regional markets; Leapfrogging to modern and energy-efficient technologies in transport, industrial sectors, and buildings) (EPA, 2011). Implementing the initiatives would also offer important co-benefits such as improved public health, through better air and water quality, and would promote rural economic development by increasing soil fertility and food security.

There are many studies that have investigated the impacts of climate change on agriculture and possible adaption measures using different models globally. Parry et al. 2004 have studied the different impact of climate change on crop yields, production, and risk of hunger with expected losses of up to 30 percent in developing countries, especially significant in Africa and parts of Asia. Agricultural GDP in Tanzania is simulated to be 11.5 percent below the baseline in the DRY scenario by the end of the 2040s (Arndt et al. 2010). This reduced productive capacity also limits growth in exports and growth in household incomes and consumption hence reducing the overall capacity of the economy. Climate variability in Zambia is projected to cost US\$ 4.3 billion over a 10-year period and might reach as high as $\$ 7.1$ billion in a worst-case rainfall scenario, by using a hydro-crop model with a dynamic computable general equilibrium (DCGE) model (Thurlow et al. 2007). In China 1.3 percent decline of agricultural share in GDP by 2080 has been reported by Zhai et al. (2009) using a CGE model. Agricultural output would become slow which ultimately leads to output losses except wheat which showed enhancement in output because of increase in global wheat demand. Reid et al. (2008) used static CGE model and found that the Namibia total GDP is reduced by between 1.1 percent and 2.6 percent, for the best-case agricultural scenario, and up to 5.8 percent in the worst-case scenarios when fishing impact is included. In the combined worst case scenario for agricultural and fishing, the urban and rural households who own capital within agriculture and business would be least affected, while poorer and rural household groups within subsistence agriculture would be severely affected by climate change.

Different authors have studied the impacts of climate change on the agricultural output in Ethiopia and projected to be from 5 to 10 percent lower than in the no-climate change baseline. There is also a general agreement that the climate change impacts will be different for the different agroecological zones (De- 
ressa \& Hassen, 2009; World Bank, 2008; Robinson et al., 2011). The net crop revenue impact of predicted climate scenarios from three models (CGM2, HaDCM3 and PCM) for the years 2050 and 2100 in Ethiopia has indicated that there would be a reduction in crop net revenue per hectare by the years 2050 and 2100 (Deressa \& Hassen, 2009). Increasing temperature marginally during winter and summer reduces the net revenue per hectare by US\$997.85 and US\$1277.28, respectively. However, the impacts are not uniformly for the different agroecological zones (AEZ) of the country. Gebreegziabher, Stage, et al. (2011) considered climate change implications on Ethiopia's agriculture by agroecology using Ricardian model disaggregating the impact of climate change on crop or livestock agriculture. The result showed the marginal effects of the climate variables on crop/livestock/farm net revenue per hectare indicate different results for temperature and precipitation and also for crop, livestock and mixed agriculture.

The impacts in 2030 on GDP are progressively worse as the climate change induced shocks become harsher (World Bank, 2008). In the worst-case scenario, real GDP in the final year would be 46 percent lower than in the base run. While productivity shocks occur only in the agricultural sectors, the negative impact is spread across the economy. A simulation result of the CGE model showed that 5.5 percent reduction in the agricultural output has created a 10 percent increase in the price level (Wolde, 2008). The same study revealed that from the industrial sector, public agro industry suffers the most damage of 17 percent reduction in output from climate change.

Robinson et al. (2011) examined the impact of climate change on GDP, consumption and income using DCGE of Ethiopia with a system of country-specific hydrology, crop, road and hydropower engineering models and concluded that the GDP will be lower by 10 compared to the no-climate change baseline by 2050 and the climate change impacts hurting the poor more.

Most of these studies focused on the microeconomics of climate change gave the partial picture of the impact of climate change on the Ethiopian economy. The studies are too restrictive by only focusing on the agricultural sector and indicate only the partial equilibrium impact on the economy. Few studies looked into the impacts of climate change in Ethiopia in general or its economy-wide impact in particular. However, climate change has area-specific effects above the household or micro level. For example, agro ecology-based analyses may provide better insight into the impact of climate change. This paper aims to fill these gaps and estimate changes in agricultural production and overall economic effect at national level and four ecological zones in Ethiopia. This study is also a first attempt by its nature to assess the consequences of changes in agricultural output on GDP, export, import, household consumption and income and other variables from the baseline path by decade from 2020 to 2050 that result from climate change.

The general objective of this study is to provide comprehensive assessment of economy-wide impact of climate change on agricultural production in Ethiopia. 
The specific objectives are the following:

- Examine impact of climate change on agricultural production and households income;

- Analyzing impact of climate change on other sectors of the economy;

- Measuring impact of climate change on macro-economic variables such as: GDP, export, and import;

- Estimating climate change's future impact on agricultural productivity across different agro ecological zones.

\section{Methodology}

\subsection{The Model and Its Calibration}

This study used a dynamic CGE model to capture the economy-wide impact of climate change on agricultural production. The model is recursive dynamic, beginning with the base year of 2009/10 and being solved annually through 2050 . The model allows analyzing the path of transitional dynamics towards a new steady state after an initial impact. This means that the model is solved for an individual year, capital stock is modified each period because of depreciation and investment, and the new values for the capital stocks are used in the solution for the subsequent year. New capital is distributed among sectors based on each sector's initial share of aggregate capital income. In addition to this, the size of the population and the growth rates of labor supply, are updated from one year to the next. Total labor supply is updated by the population growth rate ( 3 percent), i.e. as population grows, the total labor supply increases at the same rate.

The model is calibrated to a social accounting matrix (SAM) for the year 2005/06 but updated for 2009/10 by Ethiopian Development Research Institute (EDRI, 2009). The Ethiopian SAM captures all real income and expenditure flows in the economy for the year 2009/10 and includes:

- 113 activities (with 77 agricultural activities by agro ecological zones( AEZ));

- 64 commodities;

- 16 factors (by AEZ except capital): labor, land, and capital. To capture existing differences in labor markets, the model classifies employed labor into different sub-categories, including skilled, semi-skilled and unskilled workers based on occupational categories; and

- 13 institutions including 12 households: rural poor, rural non-poor, small urban poor, small urban non-poor, large urban poor, and large urban non-poor. Rural poor and non-poor disaggregating by AEZ.

- The SAM also has different taxes, saving-investment, inventory, and rest of the world accounts to show the interaction of different economic agents.

The SAM disaggregates agricultural production and income generation regionally for the five main agro-ecological zones of Ethiopia (humid lowlands moisture reliable; moisture sufficient highlands; moisture sufficient highlands; drought prone highlands and pastoralist arid lowland plains). This disaggregation of production allows the CGE model to capture how climate conditions 
vary across zones, and how climate affects crops differently according to their agronomic characteristics. The SAM disaggregates agricultural activities, land and rural households geographically by agro-ecological zones (AEZ). The regional disaggregation of crop production for each activity is based on value shares derived from the Agricultural Sample Survey for 2005/06.

\subsection{The Closure of the Model}

Equilibrium in a recursive dynamic CGE model is captured by a set of macro closures in a model. The closure rules determine how the macro economy and the factor markets work. The model provides three different options in factor market: first skilled labor and capital are assumed to be fully employed and activity-specific; second semi-skilled and un-skilled labor are assumed to be unemployed and mobile across sectors. Land is set fully employed and mobile across sectors.

Fundamentally, the ability of CGE models to analyze events depends on their specification of mechanisms for achieving equilibrium (i.e. macro closures) in three major macroeconomic balances: the fiscal balance; the savings-investment balance and external trade balance. The closure rules for this paper, government savings are flexible; direct tax rate is fixed implying the government finances its deficit through borrowing and constrained in raising taxes to cover additional public spending. For savings-investment balance, savings-driven investment closure is adopted in which investment adjusts endogenously to the availability of loan able funds. For external balance, foreign savings are fixed and exchange rate is flexible which implies during shortage of foreign savings the real exchange rate adjusts by simultaneously reducing spending on imports and increasing earnings from export.

\subsection{Simulation Assumptions}

The CGE model uses the outputs from a Ricardian model study by Deressa and Hassan (2009) on the impact of climate change on agriculture to calibrate a hypothetical general equilibrium in 2050. Total factor productivity (TFP) (alphava) is used for the simulations. Total Factor Productivity (TFP) is the portion of output not explained by the amount of inputs used in production. Productivity impacts in crop agriculture enter the model in the form of zone-specific annual shocks to the TFP parameters of the agricultural production functions. Hence, the shift parameter for CES activity production function (alphava) is used for the simulations as shown in the following aggregate value-added production function. The equation states that, for each activity, the quantity of value-added is a CES function of disaggregated factor quantities.

$$
\begin{aligned}
& Q V A_{a}=\alpha_{a}^{v a} \cdot\left(\sum_{f \in F} \delta_{f a}^{v a} \cdot Q F_{f a}^{-p_{a}^{v a}}\right)^{\frac{1}{\rho_{a} a}} \\
& {\left[\begin{array}{c}
\text { quantity aggregate } \\
\text { value added }
\end{array}\right]=\mathrm{CES}\left[\begin{array}{c}
\text { factor } \\
\text { inputs }
\end{array}\right]}
\end{aligned}
$$


where,

$f \in F\left(=F^{\prime}\right)=$ a set of factors,

$\alpha_{a}^{v a}=$ efficiency parameter in the CES value-added function,

$\delta_{f \alpha}^{v \alpha}=$ CES value-added function share parameter for factor $\mathrm{f}$ in activity a,

$Q F_{f \alpha}=$ quantity demanded of factor $\mathrm{f}$ from activity a,

$\rho_{\alpha}^{v \alpha}=$ CES value-added function exponent.

The equation states that, for each activity, the quantity of value-added is a CES function of disaggregated factor quantities. The exponent, $\rho_{a}^{v a}$, is a transformation of the elasticity of factor substitution: the higher this elasticity, the smaller the value of $\rho_{a}^{v a}$ and the larger the optimal change in the ratios between different factor quantities in response to changes in relative factor prices. For the agricultural sectors, preliminary climate change simulations can be carried out using the preliminary changes in the productivity levels that are likely to emerge due to climate change. The study simulated the impacts of climate change on agricultural productivity in 2050.

The current experiments consider the effects of climate change under two scenarios:

Scenario 1: assumes the national growth rate for crop net revenue per hectare is expected to decline by 15.4 percent in 2050 or 0.31 annual growth rates.

Scenario 2: On the other hand, the second scenario focused on the impact on crop net revenue per hectare across four agro-ecological zones.

\subsection{Analytical Model: The DCGE Model Specification}

The equations comprising the dynamic model are listed in Appendix. In its mathematical form, the model is a system of simultaneous, non-linear equations. The model uses the number of equations. Some of the main equations are listed below;

\section{Income Block Equations}

There are two types of income. First there is payment to factor accounts for services supplied to activities, i.e., domestic value added, and second there are payments to domestic factors that are used overseas, the value of these are assumed fixed in terms of the foreign currency. Factor incomes $(Y F)$ are therefore defined as the sum of all income to the factors across all activities (Y1)

$$
Y F_{f}=\sum_{a \in A} W F_{f} \cdot \overline{W F D I S T}_{f a} \cdot Q F_{f a}
$$

(income of factor $)=($ sum of activity payments (activity-specific wages times employment levels)

where, $Y F_{f}$ : income of factor $f$.

$W F_{f}$ : average price of factor $f$

$\overline{\text { WFDIST }}_{f a}$ : wage distortion factor for factor $f$ in activity $a$.

$Q F_{f a}$ : quantity demanded of factor $f$ from activity $a$.

The income equation block specifies the factor payments of the economy and their distribution to households and other institutions as well as tax payments, 
savings, remittances, and other foreign payments. In this model, households earn their income from labor. They also receive dividends, intra household transfers, government transfers and remittances.

$$
\begin{aligned}
Y I_{i}= & \sum_{f \in F} Y I F_{i f}+\sum_{i^{\prime} \in I N S D N G^{\prime}} T R I I_{i i^{\prime}}+t r n s f r_{i g o v} \cdot \overline{D P I} \\
& + \text { trnsfrirow } \\
& \cdot E X R, \quad i \in I N S D N G
\end{aligned}
$$

where, $Y I_{i}$ : income of households;

$\overline{D P I}$ : producer price index for domestically marketed output;

$T R I_{i i^{\prime}}$ : transfers from transfer from government to household;

EXR : exchange rate.

Disposable income or income after tax is either saved or used to buy domestically produced goods and imports, and to payments of transfers. The income is split among domestic institutions in fixed shares after payment of direct factor taxes and transfers to the rest of the world. The latter are fixed in foreign currency and transformed into domestic currency by multiplying by the exchange rate. This equation makes reference to the set of domestic institutions (households, enterprises, and the government), a subset of the set of institutions, which also includes the rest of world.

\section{Household Consumption Expenditure}

Consumers are assumed to maximize their utility, subject to the budget constraint. Total utility is a function of the utility derived from the different consumer goods. Many models of consumption are based on individual optimization of utility, where an individual makes consumption decisions over some period, based upon their earnings and wealth, and preferences for present and future consumption.

$$
E H_{h}=\left(1-\sum_{i \in I N S D N G} \operatorname{shii} i_{i h}\right) \cdot\left(1-M_{P} S_{h}\right) \cdot\left(1-T_{I N S}\right) \cdot Y I_{h}, h \in H
$$

(household income disposable for consumption) $=$ (household income, net of direct taxes, savings, and transfers to other non-government institutions)

where, $E H_{h}$ : consumption spending for household.

$M P S_{i}:$ Marginal propensity to save for domestic non-government institution (Exogenous variable).

This block of equations contains households' group demand. For household $\mathrm{h}$, in the above equation, the total value of consumption spending is defined as the income that remains after direct taxes, savings, and transfers to other domestic non-government institutions.

\section{Trade Block Equations}

\section{Exports}

In a country like Ethiopia, it is reasonable to assume that Ethiopia is a price-taker in the markets for our exports. Export volumes respond to a change the relative price of exports. Therefore, a change in world growth affects exports through its impact on the foreign price for exports. The other prices that affect the supply of exports are the prices of production inputs, wages and import 
prices. Export supply increases in response to lower wages and import prices.

$$
\frac{Q E_{c}}{Q D_{c}}=\left(\frac{P E_{c}}{P D S_{c}} \cdot \frac{1-\delta_{c}^{t}}{\delta_{c}^{t}}\right)^{\frac{1}{\rho_{c}^{t}-1}}, c \in(C E \cap C D)
$$

(export domestic supply ratio $)=\mathrm{f}($ export domestic price ratio $)$

where, $P E_{c}$ and $P D S_{c}$ are the export and domestic prices, respectively. This equation constitutes the first-order conditions for maximization of producer revenues given the two prices and subject to the CET function and a fixed quantity of domestic output. The equation assures that an increase in the export-domestic price ratio generates an increase in the export-domestic supply ratio.

\section{Import}

The production block also determines equilibrium imports in the dynamic model. Since imports are considered to be an intermediate input, higher wages lead to an increase in imports as firms substitute imports for labor. The first order conditions for cost minimization given the two prices and subject to the Armington function and a fixed quantity of the composite commodity yields the following import domestic demand ratio:

$$
\frac{Q M_{c}}{Q D_{c}}=\left(\frac{P D D_{c}}{P M_{c}} \cdot \frac{\delta_{c}^{q}}{1-\delta_{c}^{q}}\right)^{\frac{1}{1+\rho_{c}^{q}}}
$$

(Import domestic demand ratio $)=\mathrm{f}($ domestic import price ratio $)$

where, $P D D_{c}$ and $P M_{c}$ are the prices of domestic output and import, respectively. As result of this specification, $P D D_{c}$ is no longer equal to $P M_{c}$ and $P D D_{c}$ is endogenously determined in the model. The equation defines the optimal mix between imports and domestic output. Its domain is thus limited to imports with domestic production. The equation assures that an increase in the domestic-import price ratio generates an increase in the import-domestic demand ratio (that is, a shift away from the source that becomes more expensive).

\subsection{Data Input and Design of Simulation Scenarios}

To simulate the impact of climate change in the CGE model, the study considered the projected impact of climate change on crop net revenue per hectare at the national level and across agro ecological zones also estimated from Deressa and Hassen (2009) by considering Parallel Climate Model (PCM) model. Overall, the PCM suggests that Ethiopian's climate will become warmer and more precipitation as a result of climate change by 2050 . Based on this model more regular heavy rainfall events are expected. This allows identifying differences in the productivity of land in different climatic conditions. The reduction in net revenue per hectare was modeled across eleven agro ecological zones, but this study merged these agro ecological zones into five based on the area classification of SAM. In general, net productivity impacts from the Ricardian model are directly passed to the Ethiopian general equilibrium model through productivity shocks. 


\section{Results and Discussions}

\subsection{Impact of Climate Change on Agricultural Production}

Agricultural production in Ethiopia will decline due to climate change. In the first scenario, where the national simulated crop production falls, decreases in production of all major crop species are simulated in the coming four decades. Teff, maize and sorghum are expected to decline by 25.4, 21.8 and 25.2 percent, respectively by 2050 compared to the base period (Table 1 ). Barley and wheat production are highly affected by climate change ( 30 and 25.5 percent, respectively in 2050). On the other hand, major export crop items like pulse and oil seed production losses are estimated about 25.2 and 12.0 percent, while vegetable and fruit production to be 22.7 and 26.8 percent.

Table 1. Production in million tons in the first scenario by decade.

\begin{tabular}{|c|c|c|c|c|c|}
\hline Crop items & Simulation & 2020 & 2030 & 2040 & 2050 \\
\hline \multirow{2}{*}{ Teff } & Base & 451.7 & 926.8 & 1770 & 2964.9 \\
\hline & Climate & 437.8 & 828.9 & 1452.9 & 2210.3 \\
\hline \multirow{2}{*}{ Barley } & Base & 322.6 & 736.2 & 1461.6 & 2446.0 \\
\hline & Climate & 308.5 & 638.4 & 1149.1 & 1712.7 \\
\hline \multirow{2}{*}{ Wheat } & Base & 727.8 & 1568.9 & 2741.2 & 4139.1 \\
\hline & Climate & 669.2 & 1328.7 & 2204.1 & 3084.5 \\
\hline \multirow{2}{*}{ Maize } & Base & 682.3 & 1227.2 & 2066.7 & 3134.3 \\
\hline & Climate & 661.6 & 1113.6 & 1748.1 & 2451.5 \\
\hline \multirow{2}{*}{ Sorghum } & Base & 594.9 & 1280.3 & 2524.8 & 4411.0 \\
\hline & Climate & 572.4 & 1137.9 & 2070.7 & 3297.3 \\
\hline \multirow{2}{*}{ Pulse } & Base & 228.2 & 394.5 & 568.4 & 654.7 \\
\hline & Climate & 217.5 & 347.8 & 465.2 & 489.7 \\
\hline \multirow{2}{*}{ Oilseed } & Base & 111.1 & 153.6 & 212.1 & 293.2 \\
\hline & Climate & 107.4 & 143.9 & 192.6 & 257.9 \\
\hline \multirow{2}{*}{ Vegetable } & Base & 185.7 & 342.9 & 582.7 & 876.5 \\
\hline & Climate & 179.7 & 309.4 & 488.3 & 677.3 \\
\hline \multirow{2}{*}{ Fruit } & Base & 105.2 & 214.4 & 392.3 & 612.7 \\
\hline & Climate & 100.4 & 188.7 & 316.7 & 448.3 \\
\hline \multirow{2}{*}{ Chat } & Base & 16.5 & 22.2 & 29.7 & 39.7 \\
\hline & Climate & 15.9 & 20.8 & 26.9 & 34.9 \\
\hline \multirow{2}{*}{ Coffee } & Base & 27.3 & 41.2 & 62.9 & 93.2 \\
\hline & Climate & 26.3 & 38.5 & 56.3 & 81.9 \\
\hline \multirow{2}{*}{ Other Crop } & Base & 323.4 & 518.9 & 629.6 & 590.3 \\
\hline & Climate & 308.3 & 467.1 & 549.9 & 500.6 \\
\hline
\end{tabular}


The result is in line with the earlier findings that climate change has already significantly impacted agriculture (Lobell et al. 2011) and is expected to further impact directly and indirectly food production. The decline is due to the increase of mean temperature; changes in rain patterns; increased variability both in temperature and rain patterns; changes in water availability; the frequency and intensity of drought and floods (Simane et al. 2012). The extent of these impacts will depend not only on the intensity and timing (periodicity) of the changes but also on their combination, which are more uncertain, and on local conditions.

A decreasing in supply on agricultural production has a direct causation on price hence price rise of agricultural commodities will raise. Increasing prices of agricultural goods also leads to changes in relative commodity prices which affects the overall price. The simulation results suggest that climate change induced price increases for food will decline household's income and consumption. Furthermore, a slowdown in national economic activity driven by climate change related effects is likely to result in a decline in the demand for agricultural products. The major reduction in crop output can easily spread to the other sectors of the economy. In turn influences the purchasing capacity that lessens welfare of households.

\subsection{Impact on Non-Agricultural Production}

Since agriculture has large contribution to the economy and has linkages to non-agriculture sectors, an impact on agriculture sector adversely impacts industry and service sectors of the economy. In the first scenario, where the national productivity of agricultural production falls, the output in industry and services sector will decline in the coming four decades. The simulation result of this scenario suggests the reduction in total agricultural crop production leads to higher losses in industrial sector, and also the value of grain mill products and prepared foods will decline by 27.6 and 24.9 percent in 2050 (Figure 1). The service sector trade is also projected to decline by 24.6 percent and 33.9 percent, while hotel service decrease by 18.2 and 24.3 percent by 2040 and 2050, respectively.

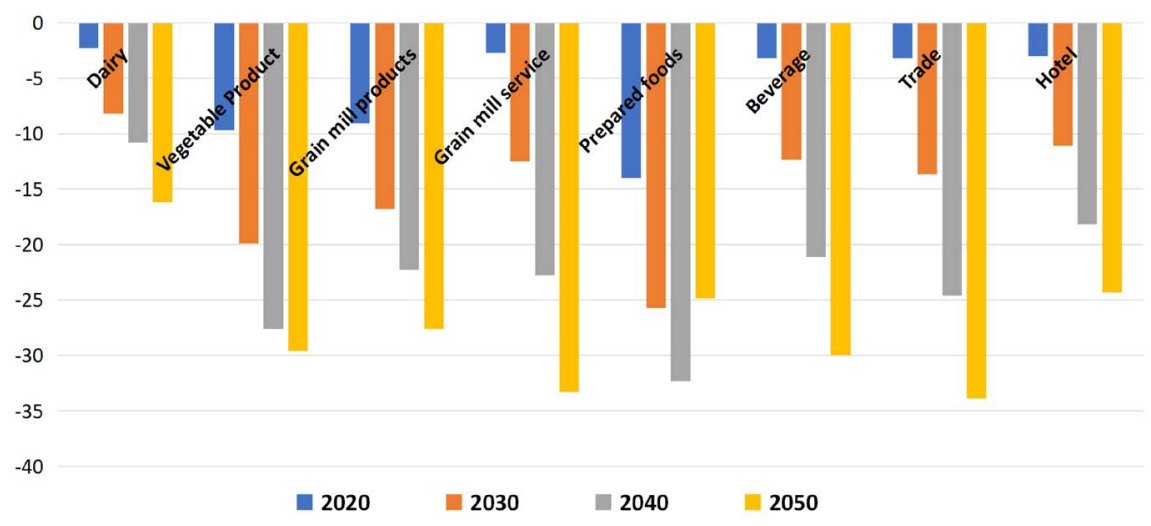

Figure 1. Percentage change on industrial and service sector at national level. 


\subsection{Impact on Household Income}

Raising the prices for staple commodities may result in a substantial reduction in real income and increase poverty of households since there food consumption takes is the highest share of consumption budget. In the first scenario, where the national productivity of crop agriculture declines, the income of rural households is highly affected by climate change. Overall, the DCGE model result indicates that the income of rural non-poor households will decline by 20.8 percent by 2050 , while the poor households are projected to decline by 20.4 percent in the same year (Table 2).

Most notably, poor households in the rural non-farming households and urban households have the lowest initial per capita income and are expected to experience the biggest income losses. Because they suffer as they do not benefit from higher prices for agricultural goods and at the same time they spend a higher proportion of their income on food expenditure, which make them particularly vulnerable to food price changes. As a result of the crop productivity losses, the income of the poor in rural non-farming is projected to decline by 20.2 percent by the end of the study period, while non-poor is expected to decline by 18.5 for the same year. By 2050, the income of poor households among urban residents rely on skilled labor will decline by 20 percent as compared to the baseline.

The impacts of climate change on household income vary across the different agro-ecologies of the country (Table 3 ). In drought prone highlands, climate change impacts tend to hurt the poor more. The amounts of losses are estimated to be 26.8 percent in 2050. In pastoralist region, the non-poor rural households' real income will decrease by 4.9 percent, while the poor households gain 6.8 percent in 2050 .

Urban and rural non-farming households are also adversely affected due to climate change especially the poor. The poor households are projected to be highly affected due to the joint effect of being net food buyers who spend a high share of their income on food and of earning incomes from factors of production most affected by climate change, namely, skilled labor, capital and unskilled labor. As income of the poor among rural non farming urban households are predicted to decreases from 16.7 and 16.3 percent in 2050, respectively.

Table 2. Percentage changes on household income due to climate change at national level.

\begin{tabular}{ccccccc}
\hline \multirow{2}{*}{ Year } & \multicolumn{2}{c}{ Rural } & \multicolumn{2}{c}{ Rural Non Farming } & \multicolumn{2}{c}{ Urban } \\
\cline { 2 - 7 } & Poor & Non poor & Poor & Non poor & Poor & Non poor \\
\hline 2020 & -2 & -2.3 & -2.9 & -1.8 & -2.7 & -1.7 \\
2030 & -8.9 & -9.4 & -9.5 & -8.3 & -9.4 & -7.8 \\
2040 & -14.7 & -15.4 & -15.2 & -13.7 & -14.8 & -13.3 \\
2050 & -20.4 & -20.8 & -20.2 & -18.5 & -20 & -18.2 \\
\hline
\end{tabular}


Table 3. Percentage change on household income by decades and AEZ.

\begin{tabular}{ccccccccc}
\hline & \multicolumn{2}{c}{2020} & \multicolumn{2}{c}{2030} & \multicolumn{2}{c}{2040} & \multicolumn{2}{c}{2050} \\
\cline { 2 - 9 } AEZs & Poor & $\begin{array}{c}\text { Non } \\
\text { Poor }\end{array}$ & Poor & $\begin{array}{c}\text { Non } \\
\text { Poor }\end{array}$ & Poor & $\begin{array}{c}\text { Non } \\
\text { Poor }\end{array}$ & Poor & $\begin{array}{c}\text { Non } \\
\text { Poor }\end{array}$ \\
\hline Moisture Sufficient Cereals & 3 & 0.3 & -0.8 & -4.9 & -4.7 & -9.6 & -10.7 & -15 \\
Moisture Sufficient Enset & -6.1 & -4.9 & -14.8 & -12 & -21.7 & -17.3 & -27.3 & -21.6 \\
Drought-Prone & -13.9 & -9 & -26.9 & -18.1 & -35.3 & -23.5 & -40.1 & -26.8 \\
Pastoralist & 6.7 & 3 & 8.4 & 1.2 & 9.3 & -0.4 & 6.8 & -4.9 \\
Rural non farming & -2.9 & -2.3 & -8.4 & -7.1 & -12.5 & -10.8 & -16.7 & -14.6 \\
Urban & -2.7 & -2.1 & -7.9 & -6.5 & -12.2 & -10.3 & -16.3 & -14.1 \\
\hline
\end{tabular}

\subsection{Impact on Household Consumption}

Agricultural output used for human consumption is determined by the combined effects of changes in real income and food price changes. In the first scenario, where the national productivity of crop agriculture falls, the study needs to emphasize the fact that the adverse impact of the climate change on consumption for rural households is hit hardly than rural non-farming and urban households consumption. Climate change hurt more the consumption of non-poor rural households by 20.6 percent compares to the base period. The consumption of the poor households in rural non-farming and urban area will highly affected by climate change than the non-poor households. As consequence, their consumption will decrease by 19.8 and 19.5 percent for poor households in 2050, respectively (Figure 2). By the end of the simulation period the negative impact on consumption for non-poor households will reach 18.3 and 18.0 percent.

From an economy-wide perspective, the adverse impacts on consumption of poor households are higher than the non-poor rural households and vary across agro-ecologies (Table 4). However, climate change impacts tend to hurt the consumption of poor households more in drought prone area compared to the base period and severity increase over the time period investigated. Under moisture sufficient cereal based highlands, the major production zone, the income of the poor households will decline by 10.4 percent in 2050. The impact of climate change would have positive effects for poor households in pastoralist all investigated periods.

Reflecting the pattern of changes in crop production across agro ecological zones, the burden of reduction in consumption falls more heavily in urban and rural non-farming households due to rising food prices and falling real income. In the last simulation period, the poor households consumption among rural non-farming and urban households suffer more than the non-poor households due to higher prices for agricultural commodities. As consequence, their consumption will suffer by 16.3 and 15.9 percent compared to the base period, respectively. 


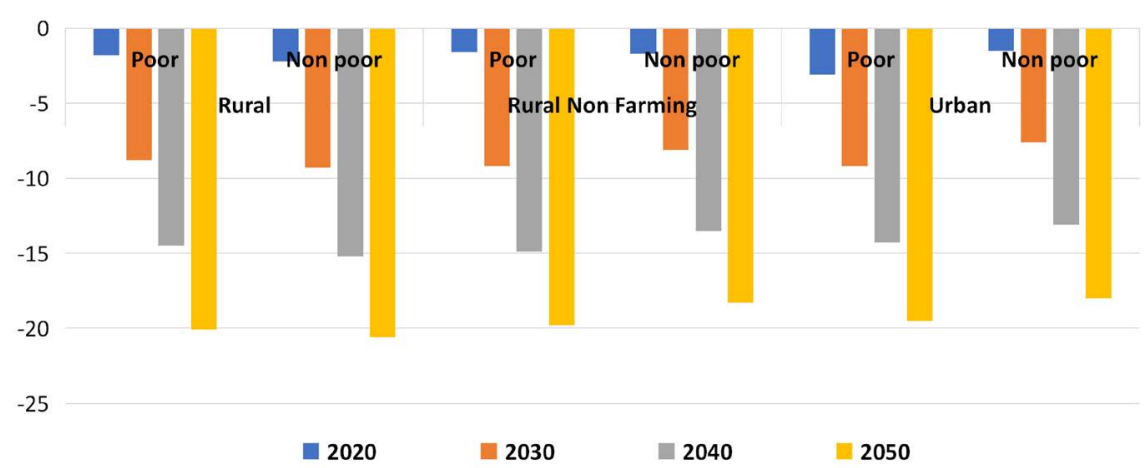

Figure 2. Percentage change on the household consumption at national level.

Table 4. Percentage change on the household consumption by decades and AEZ.

\begin{tabular}{|c|c|c|c|c|c|c|c|c|}
\hline \multirow[b]{2}{*}{ AEZs } & \multicolumn{2}{|c|}{2020} & \multicolumn{2}{|c|}{2030} & \multicolumn{2}{|c|}{2040} & \multicolumn{2}{|c|}{2050} \\
\hline & Poor & $\begin{array}{l}\text { Non } \\
\text { Poor }\end{array}$ & Poor & $\begin{array}{l}\text { Non } \\
\text { Poor }\end{array}$ & Poor & $\begin{array}{l}\text { Non } \\
\text { Poor }\end{array}$ & Poor & $\begin{array}{l}\text { Non } \\
\text { Poor }\end{array}$ \\
\hline Moisture Sufficient Cereals & 3.3 & 0.4 & -0.6 & -4.7 & -4.4 & -9.5 & -10.4 & -14.9 \\
\hline Moisture Sufficient Enset & -6.1 & -4.8 & -14.6 & -11.9 & -21.5 & -17.2 & -27 & -21.4 \\
\hline Drought-Prone & -13.6 & -8.9 & -26.8 & -18 & -35.1 & -23.4 & -39.9 & -26.6 \\
\hline Pastoralist & 7.6 & 3.3 & 8.5 & 1.6 & 9.6 & -0.2 & 7.2 & -4.5 \\
\hline Rural non farming & -2.4 & -2.2 & -8.3 & -6.9 & -12.2 & -10.6 & -16.3 & -14.4 \\
\hline Urban & -3.1 & -1.9 & -7.6 & -6.4 & -11.6 & -10.1 & -15.9 & -13.9 \\
\hline
\end{tabular}

\subsection{Impact on Macro Economic Variables}

This section discusses the impact of climate change on macroeconomic variables: absorption, total investment, export, and import and others. Total investment will decreases in the coming four decades, reflecting the necessity to replace stocks that have been lost due to climate change. Since agriculture is the main climate impact channel in our model, its declining contribution to GDP has implications for climate's damage estimates. Agricultural GDP presented as percentages from base level, are negative across the coming four decades. The modeling result shows climate change adversely affects absorption, private consumption and fixed investment gradually. The amounts will decline by 26.6, 27.8 and 26.8 percent in 2050, respectively (Table 5). Downward pressures on imports and the real exchange rate, coming from decline in household incomes. Furthermore, the reduction in household income decreases the demand for imports: the real exchange rate depreciation, stimulating export decline. The impact on real exchange rate is expected to depreciate by 6.4 percent in 2050 .

\subsection{Impact on Export and Import}

As discussed above, domestic production in Ethiopia is estimated to decline and commodity prices are projected to increase. In the first scenario, where the national productivity of crop agriculture falls, the modeling result shows that climate change adversely affects export, import and GDP. The result indicates that 
Table 5. Percentage change on major economic variable at national level by decades.

\begin{tabular}{ccccc}
\hline Variables & $\mathbf{2 0 2 0}$ & $\mathbf{2 0 3 0}$ & $\mathbf{2 0 4 0}$ & $\mathbf{2 0 5 0}$ \\
\hline Absorption & -2.7 & -10.5 & -18.5 & -26.6 \\
Private Consumption & -2.8 & -10.9 & -19.3 & -27.8 \\
Fixed Investment & -3.2 & -11.2 & -18.9 & -26.8 \\
Export & -3.7 & -16.1 & -26.4 & -35.7 \\
Import & -2.2 & -12.3 & -22.6 & -32 \\
Real Exchange Rate & -0.8 & 1.2 & 4.6 & 6.4 \\
GDP at Market price & -3.1 & -11.7 & -20.2 & -28.9 \\
GDP at Factor cost & -3.2 & -12.1 & -21.4 & -31.1 \\
\hline
\end{tabular}

real GDP at factor cost would decline by 31.1 percent compared with the base period by 2050 (Figure 3). The incorporation of agricultural productivity damage would hamper agricultural exports in Ethiopia, leading to a reduction of their aggregate exports. On the other hand, food requirements are associated more with traditional agriculture; therefore, the imports diminish only in the very short term. This is due to a series of overlapping effects. First, lower income levels induce lower imports (moreover, falling households incomes reduce demand for final non-agricultural food). Second, lower export impact on exchange rate will result lower import. Therefore, the value of export and import will fall by 35.7 percent and 32 percent by 2050 , respectively.

\subsection{Impacts of Climate Change on Factor Income}

In line with the impact of climate change on output, employment of farmers in agriculture and laborers in agro-based industries will drop. The rate of return from labor, livestock and capital will suffer from the adverse impact of climate change on agriculture productivity under the third scenario. By 2050, DCGE results indicate that incomes from livestock are adversely affected by climate change. The amount of losses is estimated to be 40.5 billion Birr (i.e. 19.2 percent) from the base period (Table 6). Due to the reduction in crop output, the income from capital and agricultural labor is projected to decline by 21.6 and 19.7 percent in 2050, respectively. On the other hand, income from land is projected to decline by 19.9. The amount of losses is estimated to 82.8 percent in 2050.

Unskilled worker real wages are largely affected by climate change as compared to the income for semi-skilled and skilled labor. The decline in wage of labors reflect the combined impact of the productivity shock in agriculture (large user of unskilled workforce) and an increment in price of both agricultural and non-agricultural commodities. The income from unskilled labors is projected to be highly affected across the coming four decades and severity increase over the time-period investigated (Figure 4). By 2050, income for unskilled labour, semi-skilled and skilled labour is expected to decline by 16.3, 10.0 and 2.7 percent, respectively. The estimated wage loss due to the adverse impact of climate 


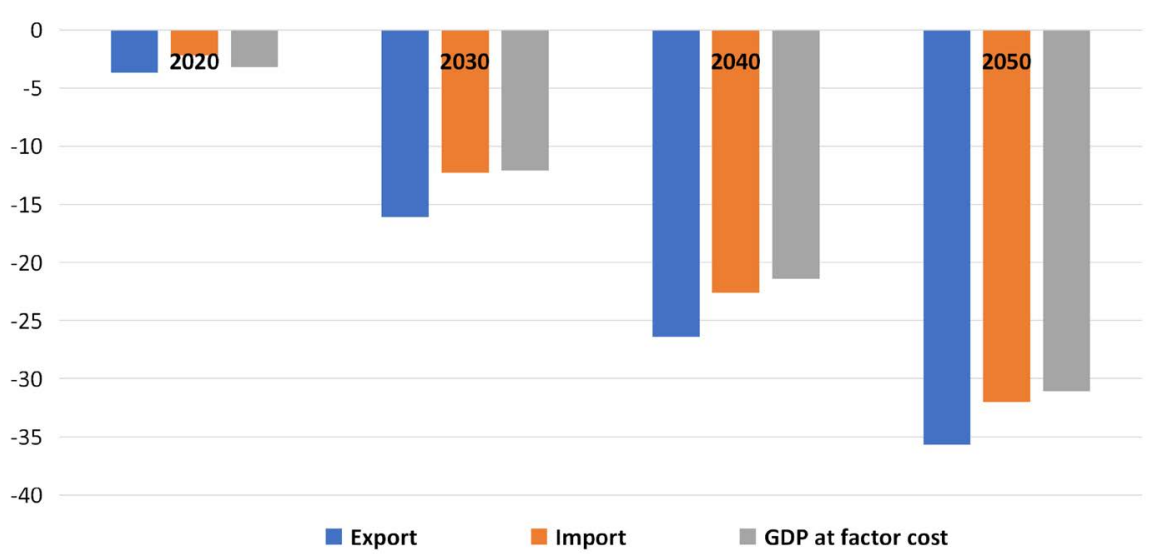

Figure 3. Percentage changes in export, import and GDP at factor cost at national level.

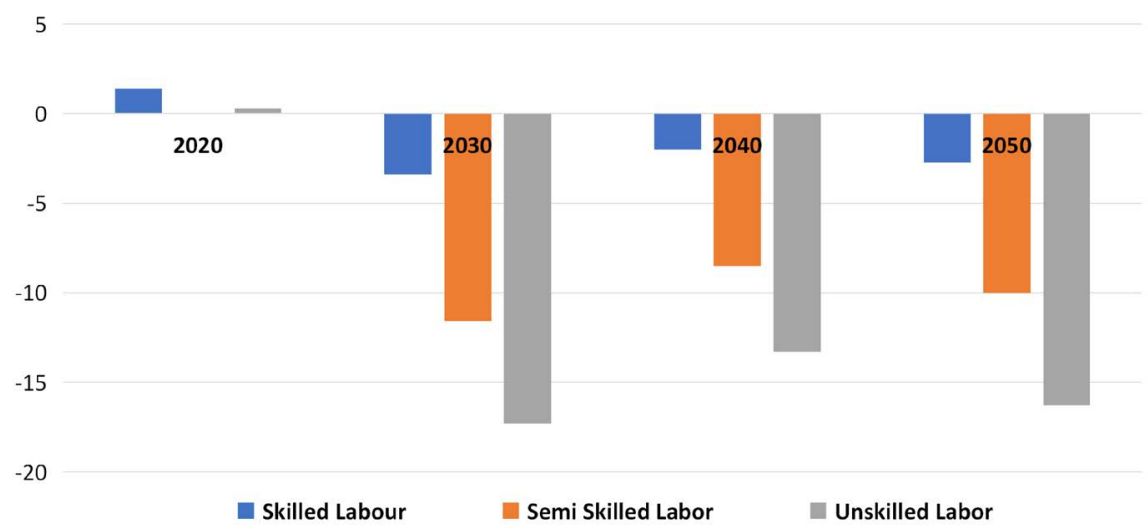

Figure 4. Percentage changes in factor income in the third scenario.

Table 6. Percentage change in factor income at national level by decades.

\begin{tabular}{ccccc}
\hline Sector & $\mathbf{2 0 2 0}$ & $\mathbf{2 0 3 0}$ & $\mathbf{2 0 4 0}$ & $\mathbf{2 0 5 0}$ \\
\hline Skilled Labor & 1.4 & -3.4 & -2 & -2.7 \\
Semi-skilled Labor & 0 & -11.6 & -8.5 & -10 \\
Unskilled Labor & -0.3 & -17.3 & -13.3 & -16.3 \\
Capital & 1.4 & -21.1 & -17.9 & -21.6 \\
Agricultural Labor & -1.6 & -8.0 & -13.5 & -19.7 \\
Land & -1.8 & -8.6 & -14.2 & -19.9 \\
Livestock & -2.6 & -8.3 & -13.4 & -19.2 \\
\hline
\end{tabular}

change is higher on the wages of skilled labor as opposed to the unskilled labor. This is in line with the findings of (World Bank, 2008).

The specific changes in productivity based on agro ecological zone will have negative impacts on factor income. The modeling result shows climate change highly affects factor income in drought prone area gradually. Simulation result shows that income of agricultural labor, land and livestock in moisture-sufficient highlands cereal-based is expected to decline by 5.1, 8.8 and 15.2 percent, respectively in 2050 compared to the base period (Table 7). On the other hand, 
Table 7. Percentage change in factor income by decades and AEZ.

\begin{tabular}{cccccc}
\hline AEZs & Factors & 2020 & 2030 & 2040 & 2050 \\
\hline \multirow{2}{*}{$\begin{array}{c}\text { Moisture Sufficient } \\
\text { Highlands Cereals }\end{array}$} & Agricultural Labor & 6.4 & 4.3 & 1.2 & -5.1 \\
& Land & 8.7 & 5.1 & 0.3 & -8.8 \\
& Livestock & -4 & -8.3 & -11.4 & -15.2 \\
\hline \multirow{2}{*}{ Moisture Sufficient Enset } & Agricultural Labor & -8.8 & -21.9 & -34.5 & -46.5 \\
& Land & -12.4 & -29.7 & -45.1 & -58.7 \\
& Livestock & -4.1 & -8.5 & -11.6 & -15.4 \\
\hline \multirow{2}{*}{ Drought-Prone } & Agricultural Labor & -21.6 & -40.9 & -56 & -67.8 \\
& Land & -28.4 & -53.5 & -71.5 & -84.3 \\
& Livestock & -4.1 & -8.5 & -11.6 & -15.5 \\
\hline \multirow{2}{*}{ Pastoralist } & Agricultural Labor & 13.7 & 18.5 & 23.2 & 23.9 \\
& Land & 12.7 & 14.2 & 14.9 & 10.3 \\
& Livestock & -4 & -8.5 & -11.6 & -15.4 \\
\hline
\end{tabular}

moisture sufficient enset based areas also highly affected by climate change in all simulation period. By 2050, the impact on the income from labor and livestock in moisture sufficient enset based areas will decline by 46.5 and 15.4 percent, respectively.

\section{Conclusion and Recommendations}

This study has examined the impact of climate change on agricultural production and the overall economy through changes in agricultural productivity in Ethiopia. Generally, climate change as assessed using the DCGE model until 2050 could well worsen Ethiopian economic performance. The largest output reduction could be seen for staple crop items. Decreasing output of these commodities will harm the food security condition in Ethiopia because climate change will directly increase production risk. From the industry sector, the result suggested that the reduction in total agricultural crop production led to higher losses in vegetable product (29.6 percent), grain mill products (27.6 percent), and prepared food (24.9 percent) by 2050, respectively, as compared to the baseline. From service sector, trade is projected to decline by 33.9 percent, while hotel service decreases 24.3 percent by 2050 .

Negative impacts for GDP are mostly due to the worsening of negative growth of agricultural sectors. The results of the CGE simulations suggest that climate-change-induced higher national food prices will lower Ethiopian overall GDP growth, factor income, decrease real household incomes and consumption. The poor rural households are highly affected than urban and rural non-farming households. The value of export and import will fall by 35.7 and 32 percent in 2050, respectively.

The productions of most crops across all agro ecological zones are projected 
to decrease over time due to climate change. The simulation result indicated that the climate change negatively affected the income from factors in all agro ecological zones except the income from labor and land in pastoralist regions. The incomes from labor, land and livestock in moisture-sufficient highlands cereal-based are expected to decline by 5.1, 8.8 and 15.2 percent in 2050. Climate change impact on factor income more severs for drought prone areas.

The government should therefore play a more critical role in encouraging adaptations. In the shorter term, Government's Growth and Transformation Plan (GTP) has already actions designed a plan to deal with impact of climate change in the years from 2010/11-2014/15. However, since impact of climate change is going to be more intensified, government has to set a longer-term plan for adaptation mechanism before the worst situation has come. This paper recommends the following adaptation mechanisms that will help Ethiopia deal with impacts of climate change.

$\checkmark$ Increase the use of irrigation and Infrastructure development: Infrastructure needs include maintenance of roads, irrigation infrastructure such as the provision of immovable equipment, dam construction, installation of wind and solar energy systems for the exploitation of groundwater resources, provision of health and education sector.

$\checkmark$ Building human capital: especially on the skill of our farmers regarding how they can mitigate the impact of climate change.

$\checkmark$ Integrated policy options are needed, including changes in modern technology and enhanced stakeholder awareness to adapt to adverse climate change impacts.

\section{Acknowledgements}

This research was funded by NILE-NEXUS: Opportunities for a sustainable food-energy-water future in the Blue Nile Mountains of Ethiopia. Belmont Forum. Addis Ababa University and John Hopkins University have also supported this research.

\section{Conflicts of Interest}

The authors declare no conflict of interest.

\section{References}

Arndt, C., Farmer, W., Tarp, F., Strzepek, K., \& Thurlow, J. (2011). Climate Change, Agriculture, and Food Security in Tanzania. Working Paper, No. 2010/101, Helsinki: UNU-WIDER (United Nations University-World Institute of Development Economics Research). https://doi.org/10.1596/1813-9450-6188

Arndt, C., Strzepeck, K., Tarp, F., Thurlow, J., Fant, C., \& Wright, L. (2010). Adapting to Climate Change: An Integrated Biophysical and Economic Assessment for Mozambique. Working Paper, No. 2010/101, Helsinki: UNU-WIDER (United Nations University-World Institute of Development Economics Research).

Deressa, T., \& Hassan, R. M. (2009). Economic Impact of Climate Change on Crop Pro- 
duction in Ethiopia: Evidence from Cross-Section Measures. Journal of African Economies, 18, 529-554. https://doi.org/10.1093/jae/ejp002

EDRI (Ethiopian Development Research Institute) (2009). Ethiopia: Input Output Table and Social Accounting Matrix. Addis Ababa.

EPA (Environmental Protection Authority) (2011). Ethiopia's Vision for a Climate Resilient Green Economy.

Gebreegziabher, Z., Kassahun, M., \& Mekonnen, A. (2011). Crop-Livestock Inter-Linkages and Climate Change Implications on Ethiopia's Agriculture: A Ricardian Approach. Climate Change Workshop, 20 July 2011.

Gebreegziabher, Z., Stage, J., Mekonnen, A., \& Alemu, A. (2011). Climate Change and the Ethiopian Economy: A Computable General Equilibrium Analysis. Environment for Development. EfD DP 11-09.

IPCC (Intergovernmental Panel on Climate Change) (2007). Climate Change: Synthesis Report. Valencia.

McSweeney, C., New, M., \& Lizcano, G. (2010). UNDP Climate Change Country Profiles: Ethiopia.

MoFED (Ministry of Agriculture and Rural Development) (2013). Annual Progress Report for the Year 2011/12 GTP Period. Addis Ababa.

Parry, M. L., Rosenzweig, C., Iglesias, A., Livermore, M., \& Fischer, C. (2004). Effects of Climate Change on Global Food Production under SRES Emissions and Socio-Economic Scenarios: A New Assessment. Global Environmental Change, 14, 53-67. https://doi.org/10.1016/j.gloenvcha.2003.10.008

Reid, H., Sahlén, I., Stage, J., \& MacGregor, J. (2008). Climate Change Impacts on Namibia's Natural Resources and Economy. Climate Policy, 8, 452-466.

https://doi.org/10.1080/14693062.2008.9685709

Robinson, S., Strzepeck, K., \& Willenbockel, L. D. (2011). A Dynamic General Equilibrium Analysis of Adaptation to Climate Change in Ethiopia. Working Paper, No. 2011/89, Helsinki: UNU-WIDER (United Nations University-World Institute of Development Economics Research).

Simane, B., Zaitchik, B. F., \& Mesfin, D. (2012). Climate Resilience in the Blue Nile/Abay Highlands: A Framework for Action. International Journal of Environmental Research and Public Health, 9, 610-631. https://doi.org/10.3390/ijerph9020610

Thurlow, J., Zhu, T., \& Diao, X. (2009). The Impact of Climate Variability and Change on Economic Growth and Poverty in Zambia. IFPRI Discussion Paper 00890, Washington DC: IFPRI.

Wolde, E. (2008). Global Climate Change and Its Economic Impact on Sub-Saharan Africa: Simulation of a Computable General Equilibrium Model for Ethiopia. MSc. Thesis, Oslo: Department of Economics, University of Oslo.

World Bank (2008). A Country Study on the Economic Impacts of Climate Change. Environment and Natural Resource Management Report, No. 46946-ET, Washington DC: World Bank, Sustainable Development Department, Africa Region.

Zhai, F., Lin, T., \& Byambadorj, E. (2009). A General Equilibrium Analysis of the Impact of Climate Change on Agriculture in the People's Republic of China. Asian Development Review, 26, 206-225. 